\title{
Learning Patterns, Personality Traits and Motivational Profile of Students of Dual Learning Modality
}

Patrones de aprendizaje, rasgos de personalidad y perfil motivacional de los estudiantes de la modalidad de aprendizaje dual

Padrões de aprendizagem, traços de personalidade e perfil motivacional de alunos da modalidade de aprendizagem dual

Cristina Torrelles-Nadal* (iD) orcid.org/0000-0002-8669-110x Georgina París-Mañas** (iD orcid.org/0000-0003-0985-5972 Carla Quesada-Pallarès*** iD orcid.org/0000-0002-5997-1536 Jordi Coiduras-Rodriguez *** (D) orcid.org/0000-0003-2460-2754

Para citar este artículo: Torrelles-Nadal, C., París-Mañas, G., Quesada-Pallares, C. y Coiduras-Rodríguez, J. (2020). Learning Patterns, Personality Traits and Motivational Profile of Students of Dual Learning Modality. Revista Colombiana de Educación, /(80), 33-52. https://doi.org/10.17227/rce.num79-9537

\section{(c) $(1) \Theta$}

* Doctora en Psicopedagogía. Profesora de la Universitat de Lleida, Cataluña, España. Correo electrónico: cristina.torrelles@udl.cat

** Doctora en educación. Profesora de la Universitat Autònoma de Barcelona, España. Correo electrónico: georgina.paris@uab.cat

*** Doctora en educación. Profesora de la Universitat Autònoma de Barcelona, España. Correo electrónico: carla. quesada@uab.cat

**** Doctor en Psicopedagogía. Profesor de la Universitat de Lleida. Correo electrónico: jordi.coiduras@udl.cat 


\begin{abstract}
The aim of this research article is to identify the profile of students enrolled in dual learning model and standard learning model based on personality traits, learning patterns and motivational orientation. Participants included 212 freshmen enrolled dual learning model $(\mathrm{N}=97)$ and standard model $(\mathrm{N}=115)$ in the Primary Education Degree. The participants completed 3 questionnaires: (1) Learning Combination Inventory (Johnston \& Dainton, 1996), (2) Big-Five Personality Inventory (Bermúdez, 1995), and (3) Motivational Profile Inventory (Corral, Arribas \& Fernández, 2010). The results showed that the students who enrolled in dual learning modality tend to be less open, more emotionally stable and take care of their relationships to a greater extent. The two later characteristics are essential for the typology of the learning modality because it is more complex to work and learn in two different environments than one as standard learning. Despite these results, the groups of both learning modalities are similar and therefore possible future lines are considered Future studies should be conducted with much larger samples and longitudinal design that allows corroborating (or not) that the students who study in dual learning modality are different or can vary their motivational orientations or improve their learning patterns during the course of their training.
\end{abstract}

\section{Keywords}

personality traits; learning;

motivation; primary education; higher education

\title{
Resumen
}

\section{Palabras clave}

rasgos de personalidad;

aprendizaje; motivación; educación primaria; universidad
El objetivo de este estudio es identificar cual es el perfil de los estudiantes que se matriculan en una modalidad de aprendizaje dual o tradicional teniendo en cuenta los rasgos de personalidad, patrones de aprendizaje y orientaciones motivacionales. Participaron 212 estudiantes de primer año matriculados en la modalidad de aprendizaje dual ( $\mathrm{N}=97$ ) y tradicional $(\mathrm{N}=115)$ del grado de Educación Primaria Los participantes completaron 3 cuestionarios: (1) Learning Combination Inventory (Johnston \& Dainton, 1996), (2) Big-Five Personality Inventory (Bermúdez, 1995) y (3) Motivational Profile Inventory (Corral, Arribas \& Fernández, 2010). Los resultados mostraron que los estudiantes matriculados en la modalidad de aprendizaje dual tienden a ser menos abiertos, más estables emocionalmente y cuidan sus relaciones. Estas dos últimas características son esenciales para la tipología de modalidad de aprendizaje, ya que requiere más complejidad para trabajar y aprender en dos entornos a diferencia de un único entorno como el aprendizaje tradicional. A pesar de estos resultados, los grupos de ambas modalidades de aprendizaje son similares y por consiguiente se plantean posibles líneas de futuro. Estudios futuros deberían ampliar la muestra incluyendo diseños de tipo longitudinal que permitan corroborar (o no) que los estudiantes que estudian en modalidad de aprendizaje dual pueden son diferentes o pueden variar sus orientaciones motivacionales o mejorar sus patrones de aprendizaje durante el transcurso de su formación.

\section{Resumo}

O objetivo deste estudo é identificar o perfil dos alunos que ingressam na modalidade de aprendizagem dual ou tradicional, levando em consideração traços de personalidade, padrões de aprendizagem e orientações motivacionais. Participaram 212 alunos do primeiro ano matriculados na modalidade de ensino dual ( $N=97)$ e tradicional ( $N=115$ ) do ensino fundamental. Os participantes responderam a 3 questionários: (1) Learning Combination Inventory (Johnston \& Dainton, 1996), (2) Big Five Personality Inventory (Bermúdez, 1995), e (3) Motivational Profile Inventory (Corral, Arribas \& Fernández, 2010). Os resultados evidenciaram que os alunos matriculados na modalidade dual de aprendizagem tendem a ser menos abertos, mais estáveis emocionalmente e cuidar de seus relacionamentos. Essas duas últimas características são essenciais para a tipologia da modalidade de aprendizagem, pois requer mais complexidade para trabalhar e aprender em dois ambientes em oposição a um único ambiente como o ensino tradicional. Apesar desses resultados, os grupos de ambas as modalidades de aprendizagem são semelhantes e, portanto, possíveis linhas de

N. ${ }^{\circ} 80$ futuro são consideradas. Estudos futuros devem expandir a amostra para incluir desenhos longitudinais que permitam corroborar (ou não) que os alunos que estudam na modalidade dual de aprendizagem podem ser diferentes ou podem variar suas orientações motivacionais ou melhorar seus padrões de aprendizagem ao longo de seu treinamento.

\section{Palavras-chave}

traços de personalidade; aprendizagem; motivação; ensino fundamental; universidade 


\section{Introduction}

The School of Education, Psychology and Social Work at the University of Lleida (UdL, Spain) implemented a new educational model, the dual learning modality, with students enrolled in the Primary Education Undergraduate Program during the 2012-2013 academic year. This initiative is unique in Spain, as it is the first time a dual learning model is implemented in higher education. The Spanish law does not recognize the dual learning model at the university system; however, our pilot studies have brought important advances and made it possible to establish the basis for a preliminary background. For the first time, college students at the UdL can choose between the dual learning and the standard modalities when enrolling in the Primary Education Undergraduate Program. This study wants to identify which personality traits, learning patterns and motivational orientation of students enrolled in dual learning modality influenced the decision-making process in such election. No previous studies have inquired about the characteristics of university students who enrolled in a different learning system such as the dual learning modality.

\section{Dual learning modality}

There is a strong consensus regarding the importance of training pre-service teachers to learn by reflecting on their own practical experience (Correa-Molina et al., 2010; Dewey, 1986; Korthagen and Vasalos, 2005). Teachers who are aware of their own practice, who evaluate themselves and ponder their experiences will have a broader and more developed repertoire of teaching skills and strategies (Ainscow et al., 2006). Accordingly, both in Europe and the U. S., are emerging new ways to train pre-service teachers, such as the dual learning model, which seeks to increase students' activity at schools throughout their training. In contrast, the still predominant standard model focuses on acquiring knowledge from research and its subsequent application. This model is commonly found within most of the pre-service teachers' training.

With a downstream approach, the new way of training (Boudjaoui et al., 2015) takes the form of 'theory-experience' or 'from theory to practice' (Carlson, 1999). Under a second type of approach, based on inductive reasoning, workplace situations and problems are used to structure the program and determine and specify the curriculum. Finally, in an intermediate approach, both knowledge and experience are understood to acquire a deeper meaning when they are brought together (Carr and Manzano, 1996; Smith, 2003). Integrative dual learning, considered to be the authentic dual learning model, leads to the acquisition of professional skills through the interaction of inductive processes (from practice to theory) and deductive 
processes (from theory to practice), as well as organizational aspects by combining and alternating practical periods in professional scenarios and terms of academic activity (Tejada and Coiduras, 2015).

Dual learning must be assessed in terms of its quality and the benefits it provides to the different actors involved in it: students, partner institutions, professionals and schools (Boudjaoui et al., 2015; Coiduras et al., 2015). Students who are immersed from an early stage of their training in a real work environment have firsthand experiences of tasks, habits, codes, and implicit values. This experience helps them weight the correctness of their educational choices: the potential of this particular approach concerning guidance is thus clear. Moreover, students' teaching practice facilitates and accelerates the acquisition of skills, the development of autonomy of action, and the configuration of a professional identity (Boudjaoui et al., 2015; Gijbels et al., 2017; Kaddouri, 2008; Kaddouri and Vandroz, 2008; Pantoja et al., 2013).

All of these aspects can contribute positively to students' motivation, resulting in increased involvement, initiative and responsibility for their own learning. The effects of this training praxis have been linked to faster and better professional integration (Hoeckel, 2008). Indeed, the students' placement in a career reality allows them to compare their theoretical and pragmatic knowledge, while ensuring an up-to-date awareness of the profession's practice. This, in turn, leads to a constant revision of the pertinence and functionality of the university's activity itself. Openness to firsthand experience allows universities to determine what knowledge and exercises are intrinsic to teaching practice.

Using the dual modality at university has been a deeply researched topic: its design, its organization, its benefits related to different stakeholders, etc. However, the literature on the topic does not explain the existence of specific students' profiles regarding this educational model. Thus, the aim of this study is to explore whether or not exists a distinctive pattern students who choose to study a standard learning modality versus those who choose the dual modality when enrolling in the Primary Education degree.

\section{Students from Dual the Learning Modality}

Recent studies support the idea that an undergraduate student's learning patterns usually matches with the degree teaching strategy (Prins et al., 1998; Rendón, 2013). In other words, a teaching model based on an experiential and practical approach triggers more reflective, close to the real world and practical learning patterns (Entwistle, 1988; Kolb, 1984).

Recent studies by Cela-Ranilla et al. (2011); Duff et al. (2004), Phillips et al. (2003), and McKenzie and Gow (2004) have shown a relationship among learning patterns, personality traits and success. These authors 
consider that a multicausal model approach can be a powerful tool in assessing academic performance in freshmen. However, scientists have not been able to overcome the lack of knowledge about the relationship between these variables and motivational orientation for undergraduate students' professional success. Boudjaoui et al. (2015) suggest that students from a dual learning modality need to do a tough work: they need to rethink, reorganize and transform their preliminary knowledge based on their singularities as well as the contingencies of the situation provided by their educational device.

Furthermore, this typology of education creates an effective environment of activities where students are immerse in a tension situation, which facilitates their professional development. Dual learning promotes cognitive, socio-affective and personal identity transformation (Wittorski, 2009).

In a recent study, Coiduras et al. (2017) defined different dual learning models. One of them is the integrative model, which is assumed as the real dual learning model, used in this study. This model focuses on eight pedagogical and organizational key factors: 1) partner, 2) professional activity, 3) the know-how and knowledge, 4) integrative learnings, 5) time and rhythm as an alternation between scenarios, 6) transfer between contexts, 7) monitoring and evaluation process of the student-trainee, and 8) the role of $\mathrm{ICT}^{\prime} \mathrm{s}$ in pre-service teacher training. These pedagogical keys allow us to observe the complexity of the model and figure out the challenge that students face.

Hence, dual learning modality is complex because every learner needs to create a more complete identity. First of all, the creation of a social identity was developed from biographical studies; second, the career identity was mainly determined by the interaction between their own identity and the identity of others-known as inherited identity-. The dual modality can alter the balance of both identities, so it has to offer two different spaces: an educational and a professional context (Boudjaoui et al., 2015). Constant ups and downs within both contexts enhance learners to question themselves about the different aspects of their identity (Kaddouri, 2008).

Besides, learners from the dual learning modality act into professional context before their peers from other modalities. Basically, dual learning implies that they need to acquire the habits, values and codes of their career environment, as well as their experience-based tasks (Coiduras et al., 2015). Consequently, learners must be more flexible, resilient, self-sufficient, and engaged or committed as they act constantly into both the professional and educational contexts. This modality can also increase the learners' levels of motivation, which contributes to increase the importance and responsibility of their learning. Indeed, the effects of this modality have been associated with a faster and better employability (Hoeckel, 2008). 


\section{Personality traits, learning patterns and motivational orientation of higher education students: variables in learning modalities}

The decision to start higher education studies involves various search and selection processes in which students prioritize the reasons for choosing studies that can satisfy their own motivations as well as external factors. The reasons stated by the students when choosing a university career can be based on interest towards learning and towards professional life (Abarca et al., 2012; Mancini et al., 2015; Navarro Guzmán and Casero Martínez, 2012; Valle Arias et al., 2010; Ye, 2015). Authors like Skatova and Ferguson (2014) warn that current literature has not explored students' reasons for their choice. For instance, there are no studies that highlight how personality traits, learning patterns and motivation profiles influence students' decisions about choosing a specific learning modality in higher education. Evidence suggests that knowing the reasons guiding students' choices when enrolling into a university program might be influenced by other variables yet to be explored.

\section{Personality traits}

Different researchers have studied personality traits, and proposed diverse descriptions. Even though, the dominant paradigm on personality is based on a construct which consists of big five factors (Saucier and Goldberg, 1996). The Big Five Factors Inventory is suitable for the university population (Rammstedt, et al., 2013), as well as for professionals (Soto et al., 2008).

The following are the personality traits used in our research:

»Emotional Adjustment. It measures tranquility to face everyday situations, stability and impulse control

» Extraversion. It measures courtesy and sincerity, preference for company as opposed to solitude, assertiveness, and an active and optimistic attitude

» Agreeableness. It measures amiability and confidence in others as well as a sincere, altruistic, and sensitive attitude towards others.

»Conscientiousness. It measures confidence in one's own capacities, order, and self-discipline as well as a reflective, decisive, and goal-oriented attitude towards objectives.

» Openness to Experience: Measures imagination, interest, and sensitivity to art, receptivity to one's own feelings and emotions, intellectual curiosity, and a critical attitude with a tendency to seek out new sensations. 
Thus, personality traits are elements that allow us to visualize the level of affinity students have with reality. Hence, they might be decisive in choosing a learning modality over another.

There is a wide terminological variety in the literature to describe the way people learn (Biggs, 1993; Entwistle, 1988; Kolb, 1984; Marton \& Säljö, 1976; Prins, et al., 1998; Schmeck, 1983). Learning patterns is a stable variable that can explain the essence of how students learn (Cela-Ranilla and Gisbert, 2013; Martínez-Fernández and García-Ravidá, 2012; Vermunt and Vermetten, 2004). By knowing how students learn, teachers can help them to adjust their learning process by recommending a specific learning modality.

Although the term learning styles could be considered the umbrella of this conception and is the most used in the literature, we framed our study in Johnston and Dainton's (1996) theory of learning patterns, in keeping with the Interactive Learning Model (ILM). This theoretical learning approach consists of four patterns of learning behavior (Cela-Ranilla and Gisbert, 2013):

» Sequential. In this pattern, learners follow a plan and seek step-bystep directions. They organize, plan work carefully and like to finish assignments from beginning to end without interruptions.

» Precise. In this pattern, learners look for and retain detailed information. They read and write in a highly specific way, and ask questions to find out more information.

» Technical. Technical learners like working autonomously at hands-on activities. Paper and pencil tasks are very often avoided and the learner reasons out technical ways to do things. They work alone without interference and show their knowledge by physically demonstrating skills. The technical learner likes to learn from real world experiences.

»Confluent. In this pattern, learners avoid conventional approaches and seek unique ways to complete any learning task. The learner is ready to take risks, to fail and to start again. More often than not, a confluent learner starts before all directions are given and likes to improvise.

\section{Motivational Orientation}

Literature offers a broad framework of definitions and conceptualizations about motivational orientation and, starting from different perspectives, leads to very different results among them. Several authors have tried to classify the various theories of motivation in relation to their characteristics: theories of content and process (Campbell and Pritchard, 1976), cognitive models (Vroom, 1964), hierarchy of needs model (Maslow, 1943), theory of needs (McClelland, 1985) and self-regulation approaches (Kanfer, 1990). 
By focusing on Steers and Porter's perspective (1987), motivational orientation is understood as the emphasis that drives people to action and explains why they take or choose certain decisions or activities. They refer to the specific elements that constitute or integrate a reality and the phenomenon beginning, direction, intensity, expectations, needs, etc. As long as students focus on their formative objective, they will know how to choose the modality that best fits their interest.

In keeping with McClelland's conceptual model (1985), Borgogni et al. (2004) developed a tool that measures four Motivational Orientation that guide behavior organization and preferences in the workplace:

» Focus on Objectives. People are attracted to difficult and challenging activities, and achieve excellence for the pleasure of maximizing their own possibilities.

» Focus on Innovation. People like to experience new things, exploit unfamiliar situations and work on several activities at the same time. These people like to modify consolidated solutions, change often and think creatively and divergently with respect to others.

» Focus on Leadership. They assume influential and control positions; they are driven to impose their choices and to remain in the center of attention. They like to make decisions even on behalf of others and involve them in their initiatives

» Focus on Relationship. They can work as a team and facilitate a good environment. They like to receive emotional support from others. They are driven to collaborate, to avoid any kind of conflict and to care for their colleagues.

\section{The Current Study}

Considering the variables dealt with in the present research and the difference between the requirements and demands of the learning model (dual or standard), we aim to identify the profile of the students enrolled in the dual learning and standard learning models, based on their personality traits, learning patterns and motivational orientation. We want to know if these variables influence students to enroll in one of these programs at the UdL. Therefore, we have three research hypotheses.

H1: Students' personality traits are different depending on the learning modality they enrolled in.

$\mathrm{H} 2$ : Students' learning patterns are different depending on the learning modality they enrolled in. learning modality they enrolled in. 


\section{Method}

\section{Study Design and Procedure}

The study uses a non-equivalent groups, quasi-experimental design (two groups), in which we only develop the pre-test. The intervention of the quasi-experimental design refers to the degree they were just starting when the pre-test was applied.

The study started at the beginning of the 2012-2013 academic term (September and October, 2012). At that time, data was collected to avoid the interference of variables as a pre-test measure. The study was conducted by the research team, using three instruments: the Learning Combination Inventory questionnaire; the Big-Five Personality Inventory and the Motivational Profile Inventory.

\section{Participants}

A total of 212 students participated in the study, 97 in the experimental group and 115 in the control group. Both groups consisted of students pursuing a university degree in Primary Education at the Faculty of Education, Psychology and Social Work of the UdL (Spain). The sample was based on naturally formed groups, with the experimental group consisting of dual learning model students and the control group consisting of standard learning model students. The sample was $70 \%$ female and $30 \%$ male. Students' qualifications during secondary school or previous education are slightly higher among the students who chose the dual learning $(M=9.15$, $\mathrm{SD}=1.21$ versus standard learning, $\mathrm{M}=8.53, \mathrm{SD}=1.14$ ). Nonetheless, there is no information about the influence of other factors that may determine the election of a specific learning option. The participants enrolled in voluntarily, they could withdraw from the study at any time without further explanation, and no partial responses were collected. Finally, the number of dropouts did not exceed the 10 per cent.

\section{Instruments}

The Big-five Personality Inventory (Capraraet al. 1993; Spanish validation: Bermúdez, 1995)

This instrument measures 5 dimensions and 10 sub-dimensions of personality, including a distortion scale (D). The survey consists of 132 items, each one consisting of five points Likert-scale questions (from $1=$ Strongly disagree to $5=$ Strongly agree). When students complete the survey it is possible to analyze the dimensions and five scale factors: neuroticism, 
extraversion, openness, emotion and conscientiousness. Bermúdez (2007) adapted the instrument into Spanish; this process was followed by both construct and discriminant validation processes as well as reliability analyses. Alpha coefficients of the five sub-dimensions ranged from .73 to .87.

The Learning Combination Inventory questionnaire (Johnston and Dainton, 1996; Spanish version: Cela-Ranilla et al., 2011)

This instrument is used to determine students' learning patterns; learning is the result of the temporal interplay between personal and contextual influences. Referring to the theoretical learning approach, the Learning Combination Inventory scale can be considered as a multidimensional formative scale; it consists of four patterns of learning behavior: sequential, precise, technical, and confluent. Each subscale contains seven items. The questionnaire is composed of 28 items on which respondents answer using a five-point Likert scale $(1=$ Never ever to $5=$ Always $)$. These scores are used to establish how often students use each learning patterns: Frequently (35 to 25), Sometimes (24 to 17), and Almost never (16 to 7). Cela-Ranilla and Gisbert (2013) achieved good levels of internal consistency in their Spanish version considering that it is a multidimensional formative scale (Cela-Ranilla et al., 2011; Villamizar, 2007).

\section{The Motivational Profile Inventory}

(Borgogni et al., 2004; Spanish version: Corral et al., 2010)

This scale identifies the students' motivational profile through four motivational orientations: focus on Objectives, Innovation, Leadership, and Relationship. In the scale, there are 70 items assessed as a seven-point Likert scale (from $1=$ Strongly disagree to $7=$ Strongly agree). Corral et al. (2010) conducted both translation and validation processes into Spanish. The results of the validation confirmed its internal structure; reliability was also ensured obtaining alpha coefficients between .79 and .88.

\section{Data analysis}

Once data were collected, statistical analyses were conducted using sPSS v.20 according to the research goals and hypotheses. Descriptive analyses were used to describe the data and to ensure its normality. Reliability of the different scales was also tested with this specific sample using Cronbach's alpha. Furthermore, inferential analyses (Mann-Whitney test for non-parametric samples) and multiple regression models were performed.

In regression analysis, the stepwise method was used to conduct a multiple regression model because it accounts for the significance of each independent variable in the model after its predictive capacity is 
calculated —once the non-significant variables are removed-. The model was structured like this: the dependent variable is the learning model ( $\mathrm{Y}$ ), being $0=$ standard model and $1=$ dual model; the independent variables are learning patterns: Sequential (x1), Precise (x2), Technical (x3) and Confluent $(x 4)$; the personality traits are: Extraversion (x5), Agreeableness (x6), Conscientious (x7), Emotional stability (x8) and Openness (x9); and the motivational profile focused on Objectives (x10), Innovation (x11), Leadership (x12), and Relationship (x13).

\section{Results}

Descriptive analyses provided an overview of the students' responses. Nonetheless, the inferential analyses allowed us to focus on those variables that show a different behavior depending on the learning modality students enrolled in. Table 1 shows that students in the control group have a tendency to get higher scores in the variables studied, meanwhile the experimental group students have a lower deviation in their scores. This means that even students enrolled in the dual learning modality are less open, more emotionally stable, less confluent and so compared to their peers in the standard modality. They tend to have more similar individual characteristics with their peers than the students enrolled in the standard learning modality.

Focusing on statistically significant differences, we appreciate that only 3 of the 13 variables analyzed show significant differences between students of both groups.

Table 1.

Descriptors

\begin{tabular}{lcccc}
\hline & $\begin{array}{c}\text { Experimental } \\
\text { Group M (SD) }\end{array}$ & $\begin{array}{c}\text { Control Group } \\
\text { M (SD) }\end{array}$ & $\begin{array}{c}\text { Total } \\
\text { M (SD) }\end{array}$ & $\begin{array}{c}\text { Mean differences } \\
\mathbf{U}(\boldsymbol{p})\end{array}$ \\
\hline The Big-Five personality Inventory & & & \\
\hline Extraversion & $53.48(10.01)$ & $54.31(11.53)$ & $53.95(10.88)$ & $5319.00(.361)$ \\
\hline Agreeableness & $57.17(9.46)$ & $58.73(11.33)$ & $58.05(10.57)$ & $5000.50(.106)$ \\
\hline Conscientious & $55.41(10.51)$ & $56.62(10.80)$ & $56.10(10.67)$ & $5259.00(.296)$ \\
\hline Emotional stability & $54.93(10.89)$ & $51.85(11.13)$ & $53.19(11.11)$ & $4830.50(.047)^{*}$ \\
\hline Openness & $48.66(9.41)$ & $53.73(12.06)$ & $51.52(11.25)$ & $4209.00(.001)^{* *}$ \\
\hline Learning patterns & & & & \\
\hline Sequential & $26.83(3.72)$ & $26.62(4.29)$ & $26.71(4.04)$ & $5506.00(.615)$ \\
\hline
\end{tabular}




\begin{tabular}{lcccc}
\hline & $\begin{array}{c}\text { Experimental } \\
\text { Group M (SD) }\end{array}$ & $\begin{array}{c}\text { Control Group } \\
\text { M (SD) }\end{array}$ & $\begin{array}{c}\text { Total } \\
\text { M (SD) }\end{array}$ & $\begin{array}{c}\text { Mean differences } \\
\mathbf{U}(\boldsymbol{p})\end{array}$ \\
\hline Precise & $24.24(3.07)$ & $24.26(3.73)$ & $24.25(3.46)$ & $5567.00(.712)$ \\
\hline Technical & $21.19(4.16)$ & $21.84(4.98)$ & $21.56(4.64)$ & $5296.00(.335)$ \\
\hline Confluent & $21.89(3.55)$ & $22.57(3.10)$ & $22.27(3.31)$ & $4811.50(.042)^{*}$ \\
\hline Motivational Orientation & & & & \\
\hline Objectives & $48.20(8.53)$ & $48.56(9.09)$ & $48.40(8.83)$ & $5430.00(.504)$ \\
\hline Innovation & $49.86(10.01)$ & $50.01(10.49)$ & $49.94(10.26)$ & $5591.50(.764)$ \\
\hline Leadership & $47.60(9.22)$ & $47.59(10.37)$ & $47.59(9.86)$ & $5554.00(.692)$ \\
\hline Relationship & $53.11(8.33)$ & $50.66(10.80)$ & $51.72(9.85)$ & $4871.00(.058)$ \\
\hline
\end{tabular}

Note: $M$ = Mean; SD = Standard Deviation; $U$ = Mann-Whitney test; $p$ : significance; * significant at .05; ** significant at .0O1

Source:Own elaboration.

To find out what independent variables influence students in the degree of Primary Education of the UdL in their choice for a learning model or other, we analyzed the data with a multiple linear regression model through the stepwise method. Remember that the dependent variable is the learning model being $\mathrm{Y}=1$ the dual learning model.

A significant model emerged with 3 of the 14 factors entered, reaching an adjusted $R^{2}$ of .099. This means that Openness, Emotional stability and Relationship explain $9.9 \%$ of the model's variance; thus, $90.1 \%$ of the modality choice still remains unexplained and other variables should be studied in order to fill this gap. Table 2 shows the model coefficients.

Table 2.

Stepwise method

\begin{tabular}{llll}
\hline & $\boldsymbol{B}$ & SE $\boldsymbol{B}$ & $\boldsymbol{\beta}$ \\
\hline Step 1 & & & \\
\hline Constant & .945 & .155 & $-.224^{* *}$ \\
\hline Openness & -.010 & .003 & \\
\hline Step 2 & & & $-.274^{* *}$ \\
\hline Constant & .572 & .196 & $.205^{*}$ \\
\hline Openness & -.012 & .003 & .003 \\
\hline Emotional stability & .009 & & \\
\hline
\end{tabular}




\begin{tabular}{lllll}
\hline & $\boldsymbol{B}$ & SE $\boldsymbol{B}$ & $\boldsymbol{\beta}$ \\
\hline Step 3 & & & \\
\hline Constant & .236 & .244 & \\
\hline Openness & -.013 & .003 & $-.291^{* *}$ \\
\hline Emotional stability & .009 & .003 & $.200^{*}$ \\
\hline Relationship & .007 & .003 & $.148^{*}$ \\
\hline
\end{tabular}

Note: $R^{2}=.046$ for Step 1, $\Delta R^{2}=.035$ for Step $2(p<.001), \Delta R^{2}=.018$ for Step $3(p<.001)$ ${ }^{*} p<.05 ;{ }^{* *} p<.001$

Source: Own elaboration.

$R^{2}$ can be interpreted as the effect size. Its magnitude can be assessed either in relative terms, compared to other studies, such variables, and in the same context, or by following the guidelines developed by Cohen (1988). For the purpose of our study — given the lack of similar studies in our context-, it is assumed that the $R^{2}$ obtained (0.099) indicates a low size effect for social sciences as directed by this author (Cohen, 1988).

We can confirm that the determining independent variables for choosing one learning modality or the other are the following. In terms of personality traits, there is a negative influence of the Openness or Openness to experience variables; in other words, the students of the dual learning system are neither open to new opportunities, nor curious about the external and internal environments. Likewise, they are not very interested in new ideas and unconventional values.

Another personality trait that stands out is the emotional stability variable. We find a student facing situations of life without any difficulties. Emotionally stable learners are not very likely to feel angry or upset; they usually remain spirited and manage their personal crisis.

Finally, another explanatory variable is the relationship sub-variable, belonging to the motivational profile. It indicates that students of the dual model are attentive to interpersonal relationships and are interested in establishing peaceful and friendly relations in the workplace. They seek collaborative and cooperative work and appreciate the opportunity to work in a relaxed atmosphere; therefore, they devote time and attention to others. In short, these students respect the others' and their characteristics and their demands, and care about their relationships.

In a second round of analysis, we incorporated to the model another predictor variable, gender, to control other sources of variability in the choice of the training model. However, no significant differences were observed. 


\section{Discussion}

The aim of this study was to identify the profile of students enrolled in the dual learning model versus those in the standard learning model based on personality traits, learning patterns, and motivational orientation. We wanted to know if these variables influenced students to enroll in dual or standard learning model programs at the UdL. To our knowledge, this is the first study where the students' profile in dual modality of learning is analyzed. So far, studies aimed to investigate the dual learning modality by its own: its importance based on the idea that learning from the workplace is more important and significant (Gijbels et al., 2017; Roure, 2011); the strategies of this learning modality as compared to the standard learning model; as well as the teacher teaching patterns involved in the dual learning modality (Coiduras et al., 2014; Good et al., 2006; Rendón, 2013). However there are not any published study focused on the students' profile in the dual learning system, and its impact for choosing this modality.

Coiduras et al. (2017) suggested that the dual learning model may not work for all students. For this reason, it is important to define what kind of student can benefit the most from it.

The standardized values shown in the model were used to verify our hypotheses: the results support $\mathrm{H} 1$ and $\mathrm{H} 3$, but they do not confirm $\mathrm{H} 2$. Students who enroll in the dual model training are less open and more emotionally stable, and they are focused on relationships. For the rest of the variables, we did not find any significant differences between students' characteristics in both groups.

In spite of the results of our study, we suggest that the students' profile in both modalities is similar. We can see but a little difference between groups. The students enrolled in the dual learning model show less openness, more emotional stability and respect the others and their demands, and they care about their relationships. That is to say, they tend to support traditional values and to maintain a fixed lifestyle; they are usually conventional, practical, conservative, uninformed and are not very curious (Bermúdez, 1995; Feist and Feis, 2007). Bermúdez (2007) indicates that this dimension comes to starting from the subdimensions of Openness to Culture (Ac) and Opening to experience (Ae). The first one measures the interest in staying informed, reading and acquiring knowledge. The second one measures aspects related to the favorable predisposition towards novelties, the ability to see things from different perspectives and an opening attitude towards values, styles, and different ways of life and cultures. This result contradicts what the authors suggest concerning the characteristics of this modality (Boudjaoui et al., 2015; Kaddouri, 2008). Learners in dual learning must be more flexible, resilient, self-sufficient, and engaged or committed because they are constantly acting in different contexts, both professional and educational. 
These students are emotionally stable, that is to say, if they have high values in this factor, they tend to be calm, peaceful, impassive, and satisfied with themselves. Finally, another explanatory sub-variable is the relationship variable, belonging to the motivational orientation. It indicates that students of the dual model are attentive to interpersonal relationships and are interested in establishing peaceful and friendly relations in the workplace. They seek collaborative and cooperative work, and appreciate the opportunity to work in a relaxed atmosphere; therefore, they devote time and attention to others. In short, these student respects the others and their demands, and care about their relationships. This variable is significantly different when we compare both groups, but when we analyze the profile, it is similar.

These characteristics are essential for the workplace context, as Coiduras et al. $(2015 ; 2017)$ and Gijbels et al. (2017) remark in their last research. In fact, the evidence indicates that autonomy and social support were important qualities for in-service student teachers' learning in the workplace. Boudjaoui et al. (2015) suggest that students in the dual learning modality have to adjust their educational device, and these characteristics are related to the relationship variable. Moreover, emotional stability is essential if we consider that this modality deals with different contexts, and students need to know how to use the sources available both in college (training institute, theory, teachers' typology, and others) and in the workplace (job demands, peers, supervisors, other students, and so on).

Despite these differences, the research findings suggest that the students who enroll in different modalities of learning have a similar profile. Based on the results, this research provides different empirical questions about what variables influence the choice of learning modality, and whether it promotes any changes in the profile or increases the motivation to choose one or another modality.

For this reason, it is important to develop a longitudinal design study to conduct a second round of surveys at the end of the students' final year. This new data collection will provide us with information about whether or not the modality of learning alters their profile based on personality traits, learning patterns and motivational orientation.

One of the limitations arising from this study is the sample size and place of collection because, even though the entire population was involved, its findings cannot be generalized beyond our context. Therefore, future studies should be conducted with much larger samples, different academic degrees that use the dual learning system and different universities, so that the results can be generalized to the community population. Other future studies should focus on the students once they graduate in order to examine if their learning patterns, personality traits and motivational orientation are the same for both modalities, or if the university teachers and teaching patterns have an impact on the students' profiles and outcomes. 


\section{Acknowledgements}

This research article has received a grant for its linguistic revision (translation) from the Language Institute of the University of Lleida (2015 call).

\section{References}

Abarca, N., Gormaz, N. \& Leiva, P. I. (2012). Expectativas de roles futuros de estudiantes universitarios en Chile. Universitas Psychologica, 11(2), 405-414.

Ainscow, M., Booth, T. \& Dyson, A. (2006). Improving schools, developing inclusion. Routledge. https://doi.org/10.4324/9780203967157

Bermúdez, J. (1995). Manual del Cuestionario Big Five (BFQ). TEA Ediciones.

Bermúdez, J. (2007). Cuestionario Big Five (4. ${ }^{\text {a }}$ ed.). TEA Ediciones.

Borgogni, L., Petitta, L. \& Barbaranelli, C. (2004). Test de Orientación Motivacional-TOM. TEA Ediciones.

Boudjaoui, M., Clénet, J. \& Kaddouri, M. (2015). La formación en alternancia en Francia: entre prácticas sociales y objeto de investigación. Educar, 51(2), 239-258. https://doi.org/10.5565/rev/educar.679

Campbell, J. P. \& Pritchard, R. D. (1976). Motivation theory in industrial and organizational psychology. In M. D. Dunnette (a cura di), Handbook of industrial and organizational psychology. Rand-McNally.

Caprara, G. V., Barbaranelli, C., Borgogni, L. \& Perugini, M. (1993). The "big five questionnaire": A new questionnaire to assess the five factor model. Personality and Individual Differences, 15(3), 281-288. https://doi.org/10.1016/0191-8869(93)90218-R

Carlson, H. L. (1999). From practice to theory: A social constructivist approach to teacher education. Teachers and Teaching, 5(2), 203-218. https://doi.org/10.1080/1354060990050205

Carr, W. \& Manzano, P. (1996). Una teoría para la educación: hacia una investigación educativa crítica. Morata.

Cela-Ranilla, J., Gisbert, M. \& Minelli Di Oliveira, J. (2011). Exploring the relationship among learning patterns, personality traits, and academic performance in freshmen. Educational Research and Evaluation, 17(3), 175-192. doi:10.1080/13803611.2011.599564o rg/10.1080/13803611.2011.599564

Cela-Ranilla, J. M. \& Gisbert. M. (2013). Learning patterns of first year students. Revista de Educación, 361, 171-195. https://doi.org/10.4438/1988592X-RE-2011-361-139

Cohen, J. (1988). Statistical power analysis for the behavioral sciences ( $2^{\text {nd }}$ ed.). Erlbaum. 
Coiduras, J., Correa, E., Boudjaoui, M. \& Curto, A. (2017). Formación dual en el grado de educación: claves organizativas y pedagógicas. Revista Qurriculum, 30, 81-102.

Coiduras, J., Isus, S. \& Del Arco, I. (2015). Formación inicial de docentes en alternancia. Análisis desde las percepciones de los actores en una experiencia de integración de aprendizajes. Educar, 51, 277-297. https://doi.org/10.5565/rev/educar.670

Coiduras, J., París, G. Torrelles, C. \& Carrera, X. (2014). La evaluación de competencias en una experiencia de formación dual de maestros: diferencias y semejanzas entre tutores de escuela y de universidad. Estudios Pedagógicos (Valdivia), 40, 29-48. https://doi.org/http://dx. doi.org/10.4067/S0718-07052014000200003

Corral, S., Arribas, D. \& Fernández, I. (2010). Test de orientación motivacional (TOM) Ediciones TEA.

Correa-Molina, E., Collin, S., Chaubet, P. \& Gervais, C. (2010). Concept de réflexion: un regard critique. Éducation et Francophonie, 38, 135154. https://doi.org/10.7202/1002160ar

Dewey, J. (1986). Experience and Education. The Educational Forum, 50(3), 241-252. https://doi.org/10.1080/00131728609335764

Duff, A., Boyle, E., Dunleavy, K. \& Ferguson, J. (2004). The relationship between personality, approach to learning and academic performance. Personality and Individual Differences, 36, 1907-1920.

Entwistle, N. (1988). Motivational factors in students' approaches to learning. In R. R. Schmeck (Ed.), Learning strategies and learning styles (pp. 21-51). Boston, MA: Springer US. https://doi.org/10.1007/9781-4899-2118-5_2

Feist, J. \& Feis, G (2007). Teorías de la personalidad. España: McGraw-Hill.

Gijbels, D., Kyndt, E., Peeters, L. \& Schelfhout, W. (2017). Getting out the most of the combination of working and learning: the case of teachers-in-training in Flanders. European Journal of Psychology of Education, 32(2), 183-199. https://doi.org/10.1007/s10212-016-0309-6

Good, T. L., McCaslin, M., Tsang, H. Y., Zhang, J., Wiley, C. R. H., Bozack, A. R. \& Hester, W. (2006). How well do 1st-year teachers teach: Does type of preparation make a difference? Journal of Teacher Education, 57(4), 410-430. https://doi.org/10.1177/0022487106291566

Hoeckel, K. (2008). Costs and benefits in vocational education and training. Organisation for Economic Cooperation and Development (OECD Education).

Johnston, C. \& Dainton, G. (1996). The Learning Combination Inventory. Corwin Press, Sage Publications. 
Kaddouri, M. (2008). L'alternance comme espace de transitions et de tensions identitaires. En E. Correa Molina y C. Gervais (eds.), Les stages en formation à l'enseignement : pratiques et perspectives théorique (pp. 59-82). Presses de I'Université du Québec. http://dx. doi.org/10.7202/039871ar

Kaddouri, M. \& Vandroz, D. (2008). Formation professionnelle en alternance : quelques tensions d'ordre pédagogique et identitaire. En: E. Correa Molina, C. Gervais y S. Rittershaussen (eds.). Explorations internationales: vers une conceptualisation de la situation de stage (87-115). CRP.

Kanfer, R. (1990). Motivation theory and industrial and organizational psychology. In M. D. Dunnette \& L. S. Hough (a cura di), Handbook of Industrial and Organizational Psychology. Consulting Psychologists Press.

Kolb, D. A. (1984). Experiential learning: Experience as the source of learning and development. Prentice-Hall.

Korthagen, F. \& Vasalos, A. (2005). Levels in reflection: Core reflection as a means to enhance professional growth. Teachers and Teaching: Theory and Practice, 11(1), 47-71. https://doi.org/10.1080/ 1354060042000337093

Mancini, T., Caricati, L., Panari, C. \& Tonarelli, A. (2015). Personal and social aspects of professional identity. An extension of Marcia's identity status model applied to a sample of university students. Journal of Vocational Behavior, 89, 140-150.

Martínez-Fernández, R. J. \& García-Ravidá, L. (2012). Patterns of learning in teacher education master students: Related personal and contextual variables. Profesorado. Revista de Curriculum y Formación del Profesorado 16(1), 165-182. https://recyt.fecyt.es/index.php/profesorado/article/view/48968

Marton, F. \& Sa ljo, R. (1976). On qualitative differences in learning: - Outcome and process. British Journal of Educational Psychology, 46, 4-11.

Maslow, A. H. (1943). A theory of motivation. Psychological Review, 50, 370-396.

McClelland, D. C. (1985). Human motivation. Scott Foresman.

McKenzie, K. \& Gow, K. (2004). Exploring the first year academic achievement of school leavers and mature-age students through structural equation modelling. Learning and Individual Differences, 14, 107-123.

Navarro Guzmán, C. \& Casero Martínez, A. (2012). Análisis de las diferencias de género en la elección de estudios universitarios. Estudios Sobre Educación, 22, 115-133. 
Pantoja Ospina, M. A., Duque Salazar, L. \& Correa Meneses, J. (2013). Modelos de estilos de aprendizaje: una actualización para su revisión y análisis. Revista Colombiana de Educación, 64, 79-105. https://doi. org/10.17227/01203916.64rce79.105

Phillips, P., Abraham, C. \& Bond, R. (2003). Personality, cognition, and university students' examination performance. European Journal of Personality, 17, 435-448.

Prins, F. J., Busato, V. V., Elshout, J. J. \& Hamaker, C. (1998). Een nieuwe bijdrage tot validatie van het (meta)cognitieve deel van de Inventaris Leerstijlen (ILS). A new contribution to the validation of a part of the Inventory of Learning Styles. Pedagogische Studiën, 75(2), 73-93. http://psycnet.apa.org/record/1998-10099-001

Rammstedt, B., Kemper, C. J., Klein, M. C., Beierlein, C. \& Kovaleva, A. (2013). Eine kurze Skala zur Messung der fünf Dimensionen der Persönlichkeit [Una escala corta para medir las cinco dimensiones de la personalidad]. Methoden, Daten, Analysen, 7, 233-249.

Rendón, M. (2013). Hacia una conceptualización de los estilos de enseñanza. Revista Colombiana de Educación, 64, 175-195. https://doi. org/10.17227/01203916.64rce175.195

Roure, J. (2011, December 19). Les dispositifs de professionnalisation par alternance sous contrat de travail: vers quelles transformations des pratiques pédagogiques dans l'enseignement supérieur? L'exemple de l'apprentissage en France. TDx (tesis doctorals en xarxa). Universitat de Lleida. https://www.tdx.cat/handle/10803/81417

Salgado, J. F. (1994). Manual técnico para el Inventario de Personalidad de Cinco Factores (IP/5F). Tórculo.

Salgado, J. F. (1996). Análisis exploratorio y confirmatorio del Inventario de Personalidad de Cinco Factores (IP/5F). Psicológica: Revista de Metodología y Psicología Experimental, 17, 353-366.

Saucier, G. \& Goldberg, L.R. (1996). The language of personality: Lexical perspectives on the five-factor model. In J.S. Wiggins (Ed.), The five-factor model of personality: Theoretical perspectives (pp. 21-50). Guilford.

Schmeck, R. R. (1983). Learning styles of college students. In R.F. Dillon \& R. R. Schmeck (Eds.), Individual differences in cognition (pp. 233279). Academic Press.

Skatova, A. \& Ferguson, E. (2014). Why do different people choose different university degrees? Motivation and the choice of degree. Frontiers in Psychology, 5, 1-15.

Smith, P. J. (2003). Workplace learning and flexible delivery. Review of Educational Research, 73(1), 53-88. https://doi.org/10.3102/ 00346543073001053 
Soto, C. J., John, O. P., Gosling, S. D. \& Potter, J. (2008). The developmental psychometrics of big five self-reports: Acquiescence, factor structure, coherence, and differentiation from ages 10 to 20. Journal of Personality and Social Psychology, 94(4), 718.

Steers, R. M. \& Porter, L. W. (1987). Motivation and work behavior. McGraw-Hill.

Tejada, J. \& Coiduras, J. (2015). Presentación monográfico "Educación en alternancia en educación superior. Perspectivas y experiencias". Educar, 51(2), 231-237. https://doi.org/10.5565/rev/educar.742

Valle Arias, A., Rodríguez, S., González Cabanach, R., Núñez Pérez, J. C., González Pienda, J. A. \& Rosario, P. (2010). Perfiles motivacionales y diferencias en variables afectivas, motivacionales y de logro. Universitas Psychologica, 9(1), 109-122.

Vermunt, J. D. \& Vermetten, Y. J. (2004). Patrones en el aprendizaje de los estudiantes: relaciones entre estrategias de aprendizaje, concepciones de aprendizaje y orientaciones de aprendizaje. Educational Psychology Review, 16, 359-384. 10.1007/s10648-004-0005-y

Villamizar Carrillo, L. P. (2007). Estrategias de formación de profesores universitarios para el uso de las tecnologías de información y comunicaciones (TICS) a partir del sistema de aprendizaje Let Me Learn: dos estudios de caso (tesis de doctorado). Universitat Rovira i Virgili, Tarragona.

Vroom, V. H. (1964). Work and Motivation. Wiley.

Wittorski, R. (2009). Jeter les bases d'une conception d'ensemble des liens entre activité-compétence-professionnalisation/ développement professionnel-identité. Penser L'éducation, 25(25), 143-155. https://doi.org/<hal-00601565>

Ye, L. H. (2015). Work values and career adaptability of Chinese university students. Social Behavior and Personality: An International Journal, 43(3), 411-421. 